\title{
THE EFFECT OF NITROGEN APPLICATION IN DIFFERENT DOSES BY FERTIGATION METHOD ON GRAIN YIELD, YIELD COMPONENTS AND QUALITY OF CORN (Zea mays L.)
}

\author{
SARACOGLU, M. ${ }^{1}-$ OKTEM, A. ${ }^{2 *}$ \\ ${ }^{I}$ Ministry of Agriculture Provincial Directorate, Sanliurfa, Turkey \\ ${ }^{2}$ Harran University, Faculty of Agriculture, Department of Field Crops, Sanliurfa, Turkey \\ ${ }^{*}$ Corresponding author \\ e-mail: aoktem@harran.edu.tr; phone: +90-414-318-3686; fax: +90-414-318-3682
}

(Received $1^{\text {st }}$ Jul 2021; accepted $1^{\text {st }}$ Oct 2021)

\begin{abstract}
This study was aimed to determine the most appropriate nitrogen amount for maize using fertigation method. Trials were conducted in 2018 and 2019 with 4 replicates according to the randomized blocks design in Sanliurfa, Turkey. Each plot area was $14 \mathrm{~m}^{2}(5 \mathrm{~m} \times 2.8 \mathrm{~m})$ and consisted of four rows of $5 \mathrm{~m}$ in length. DKC-6664 maize variety was used in the study as a crop material. Drip irrigation system was used with 5-day intervals according to daily evaporation values. Irrigation water was given using 1.25 coefficient of Class A Pan evaporation. Ten separate nitrogen doses were applied with the irrigation water at $0 \mathrm{~kg} \mathrm{da}^{-1}, 4 \mathrm{~kg} \mathrm{da}^{-1}, 8 \mathrm{~kg} \mathrm{da}^{-1}, 12 \mathrm{~kg} \mathrm{da}^{-1}, 16 \mathrm{~kg} \mathrm{da}^{-1}, 20 \mathrm{~kg} \mathrm{da}^{-1}, 24 \mathrm{~kg} \mathrm{da}^{-1} 28 \mathrm{~kg} \mathrm{da}^{-1}, 32 \mathrm{~kg} \mathrm{da}^{-1}$ and $36 \mathrm{~kg} \mathrm{da}^{-1}\left(1 \mathrm{da}=1000 \mathrm{~m}^{2}\right)$. According to the results of the two-year average, grain yield ranged from 434 to $1594 \mathrm{~kg} \mathrm{da}^{-1}$. The leaf area per plant varied between 112 and $621 \mathrm{~cm}^{2}$ plant $^{-1}$, protein content between $7.39 \%$ and $8.84 \%$, starch content between $70.90 \%$ and $71.62 \%$, and oil content between $4.20 \%$ and $4.66 \%$. In general, the properties examined increased from the N0 application to the N28 application. Increasing nitrogen doses applied by fertigation method had a positive effect on the investigated properties. Based on average of years, the highest grain yield was determined in $28 \mathrm{~kg} \mathrm{da}^{-1}$ nitrogen application with fertigation system. However, no statistical difference was observed between N24 and N28 applications.
\end{abstract}

Keywords: maize, $N$, drip irrigation, protein, starch, oil

\section{Introduction}

Corn is an annual hot climate cereal. It can be grown in tropical and subtropical temperate climates, and it can be cultivated almost anywhere in the world. Corn is a plant used as human food, animal feed and industrial raw material.

Stalk, leaves and grains are used as animal feed (Oktem and Oktem, 2020a). Grains and starch are used in human nutrition and in the food industry. In addition to these consumption areas, it is also consumed as a snack. Moreover, its use in the oil, sweetener industries and biofuel-bioethanol production has been increasing in recent years (Oktem and Oktem, 2020b).

Due to global warming and the gradual decrease of water resources, research and development studies on the effective use of water have increased. The use of pressurized irrigation systems such as drip irrigation has come to an important point concerning the use of water, which is an important input in the agricultural sector, at an optimum level. Drip irrigation system saves water compared to other irrigation systems and increases the effective use of water by the plant. In addition, drip irrigation system allows plant nutrients to be given in combination with irrigation water (Oktem, 2008a).

Nitrogen is absolutely essential and the most widely used plant macronutrient. The application of nitrogen fertilizers together with irrigation water in drip irrigation systems (fertigation) provides an increase in fertilizer use efficiency and yield. Therefore, 
irrigation methods and nitrogen fertilization application are key factors in increasing the yield of plants. Proper management of these two factors is necessary for environmental protection and high production (Oktem, 2008b).

Determining the appropriate fertilizer dose in the corn plant is important in terms of high efficiency, cost reduction and minimum damage to the environment. In previous studies, it was stated that the most appropriate nitrogen dose in corn plant was $25 \mathrm{~kg} \mathrm{~N} \mathrm{da}^{-1}$ (Cokkızgın, 2002).

In another study, it was stated that increasing nitrogen doses had a positive effect on vegetative parameters; however, it was stated that the applications made above $25 \mathrm{~kg} \mathrm{~N} \mathrm{da}^{-1}$ were not statistically significant (Kaplan and Aktas, 1993). Although the highest yield was obtained from $36 \mathrm{~kg} \mathrm{~N} \mathrm{da}^{-1}$ dose in the study conducted on maize plant, it was stated that statistically $27 \mathrm{~kg} \mathrm{~N} \mathrm{da}^{-1}$ dose was more appropriate (Kara, 2006).

In a study in which 5 different nitrogen doses $\left(0,24,32,40\right.$ and $\left.48 \mathrm{~kg} \mathrm{~N} \mathrm{da}^{-1}\right)$ were tested in two corn varieties (89MAY70 and Shemal), it was found that nitrogen doses positively affected the grain yield and the highest grain yields were obtained from 40 and $48 \mathrm{~kg} \mathrm{da}^{-1}$ nitrogen doses (Tunalı et al., 2012). In a study where four different nitrogen doses $\left(0,7,14\right.$ and $\left.21 \mathrm{~kg} \mathrm{da}^{-1}\right)$ were researched it has been reported that nitrogen doses have a statistically significant effect on plant height, first ear height and grain yield (Can and Akman, 2014).

It has been reported that the highest yield values were obtained from $15 \mathrm{~kg} \mathrm{da}^{-1} \mathrm{~N}$ doses in the sweet corn plant, where $0,7.5,15,22.5$ and $30 \mathrm{~kg} \mathrm{da}^{-1}$ pure nitrogen doses were applied by the fertigation method (Avsar et al., 2018).

The aim of this study is to determine the most appropriate amount of nitrogen to be applied by fertigation method in drip irrigation in maize plant and to find out the effects of applied nitrogen on yield and yield components of maize plant and quality.

\section{Material and methods}

\section{Study design and experimental procedures}

This study was carried out at the second crop conditions of the Harran Plain, Sanliurfa, Turkey in 2018 and 2019. The research was set up in a randomized block design with 4 replications. DKC-6664 single cross hybrid corn variety was used as plant material in the study. The climate data of the research area is given in Table 1, and the soil properties are given in Table 2. During the trial years, the temperature increased above $40{ }^{\circ} \mathrm{C}$ in June, July and August, and the average relative humidity was observed between $29.3 \%$ and $36.6 \%$. There was no rainfall in July and August and rainfall was very low in June and September (Table 1). There was no climatic factor limiting corn cultivation, and the plants were grown without any problems with the irrigation.

The soil of the trial area is low in organic matter, calcareous, high in potassium, and has a harmless salinity (Table 2). The soil characteristics of the experimental area are alluvial, flat and deep soils. Typical red profiles have clay texture. The entire profile is very calcareous and has a pH between 7.3 and 7.8 (Dinc et al.,1988).

Before planting, the soil was first plowed with a mouldboard plough, then processed with a goble disc and made ready for planting by pulling the float. In the experiment, each plot consisted of 4 rows with a $5 \mathrm{~m}$ length. Row spacing was $70 \mathrm{~cm}$, intra row spacing was $16 \mathrm{~cm}$ and sowing depth was 5-6 cm. Sowing was done on 25 June 2018 and 24 June 2019 with a pneumatic seed drill. Chemical spraying was done against weeds and pests. Harvesting was done when the plants were completely dry. 
Table 1. Climatic data of 2018 and 2019 years of the research area

\begin{tabular}{c|c|c|c|c|c|c|c|c|c|c}
\hline & \multicolumn{2}{|c|}{$\begin{array}{c}\text { Lowest } \\
\text { temperature }\left({ }^{0} \mathbf{C}\right)\end{array}$} & \multicolumn{2}{c|}{$\begin{array}{c}\text { Highest } \\
\text { temperature }\left({ }^{\mathbf{}} \mathbf{C}\right)\end{array}$} & \multicolumn{2}{c|}{$\begin{array}{c}\text { Average } \\
\text { temperature }\left({ }^{0} \mathbf{C}\right)\end{array}$} & \multicolumn{2}{|c|}{$\begin{array}{c}\text { Average relative } \\
\text { humidity (\%) }\end{array}$} & \multicolumn{2}{c}{$\begin{array}{c}\text { Precipitation } \\
(\mathbf{m m})\end{array}$} \\
\cline { 2 - 12 } & $\mathbf{2 0 1 8}$ & $\mathbf{2 0 1 9}$ & $\mathbf{2 0 1 8}$ & $\mathbf{2 0 1 9}$ & $\mathbf{2 0 1 8}$ & $\mathbf{2 0 1 9}$ & $\mathbf{2 0 1 8}$ & $\mathbf{2 0 1 9}$ & $\mathbf{2 0 1 8}$ & $\mathbf{2 0 1 9}$ \\
\hline April & 9.3 & 5.9 & 32.1 & 26.8 & 19.9 & 14.4 & 38.4 & 67.0 & 35.8 & 97.4 \\
May & 12.2 & 10.1 & 36.3 & 40.3 & 23.0 & 25.2 & 50.1 & 35.8 & 64.5 & 7.3 \\
June & 16.2 & 18.6 & 43.1 & 44.1 & 28.6 & 30.7 & 36.6 & 30.6 & 10.1 & 8.9 \\
July & 21.2 & 19.7 & 43.2 & 42.3 & 31.9 & 31.7 & 34.2 & 29.6 & 0.0 & 0.0 \\
August & 20.8 & 20.7 & 42.2 & 45.8 & 32.2 & 32.8 & 33.6 & 29.3 & 0.0 & 0.0 \\
September & 17.7 & 15.9 & 41.5 & 39.5 & 28.8 & 27.9 & 31.3 & 30.3 & 2.2 & 0.2 \\
October & 9.3 & 11.3 & 34.2 & 36.2 & 21.6 & 22.9 & 45.6 & 44.9 & 39.4 & 45.1 \\
November & 5.4 & - & 27.5 & - & 13.0 & - & 72.5 & - & 106.6 & 0.0 \\
\hline
\end{tabular}

Table 2. Some physical and chemical properties of the trial area soil

\begin{tabular}{c|c|c|c|c}
\hline Soil properties & \multicolumn{2}{|c|}{$\mathbf{2 0 1 8}$} & \multicolumn{2}{c}{$\mathbf{2 0 1 9}$} \\
\hline Deep & $\mathbf{0 - 2 0}$ & $\mathbf{2 0 - 4 0}$ & $\mathbf{0 - 2 0}$ & $\mathbf{2 0 - 4 0}$ \\
\hline $\mathrm{pH}$ & 7.81 & 7.91 & 7.95 & 7.87 \\
$\mathrm{EC}(\mathrm{ds} / \mathrm{m})$ & 1.31 & 1.00 & 0.91 & 0.90 \\
Lime $(\%)$ & 26.90 & 26.90 & 28.10 & 27.30 \\
Phosphorus $\mathrm{P}_{2} \mathrm{O}_{5}\left(\mathrm{~kg} \mathrm{da}^{1}{ }^{-}\right)$ & 6.42 & 4.12 & 4.69 & 4.69 \\
Potassium $\mathrm{K}_{2} \mathrm{O}\left(\mathrm{kg} \mathrm{da}^{1}\right)$ & 213.30 & 171.60 & 145.20 & 150.30 \\
Organic matter (\%) & 2.01 & 1.61 & 1.69 & 1.60 \\
Nitrogen (\%) & 0.15 & 0.14 & 0.12 & 0.12 \\
Sandy (\%) & 25.28 & 25.28 & 30.00 & 28.00 \\
Clay (\%) & 56.00 & 52.00 & 48.88 & 48.80 \\
Silt (\%) & 18.72 & 22.72 & 21.12 & 23.12 \\
\hline
\end{tabular}

An analysis-of-variance (ANOVA) was performed using Jump statistical package program to evaluate statistical differences between research results. Means of the data obtained from research were compared using DUNCAN test at $\mathrm{P} \leq 0.05$ (Yurtsever, 1984).

\section{Application of irrigation water}

Sprinkler irrigation was applied in all plots immediately after planting to obtain a sufficient output. When the plants have 3-4 leaf, nitrogen doses were started to be given to all plots with the drip irrigation system. During both trial years, laterals were placed in the drip irrigation system, one lateral to two plant rows, with $140 \mathrm{~cm}$ spacing (Oktem, 2008a).

The irrigation water to be given to the parcels was calculated as 1.25 times the 5-day cumulative evaporation amount obtained from the Class-A Pan container (Oktem, 2008a). Irrigation water was given to the parcels at 5-days intervals after correcting with the soil cover percentage of the plant (Oktem, 2006).

During the 2018 growing season of the experiment, $790 \mathrm{~mm}$ of total irrigation water was applied, and $759 \mathrm{~mm}$ during the 2019 growing season. Some chemical properties of irrigation water used in the research was given Table 3. 
Irrigation was continued until the end of the physiological maturity period of the plants. Fig. 1 shows design of drip irrigation and fertigation system in the research.

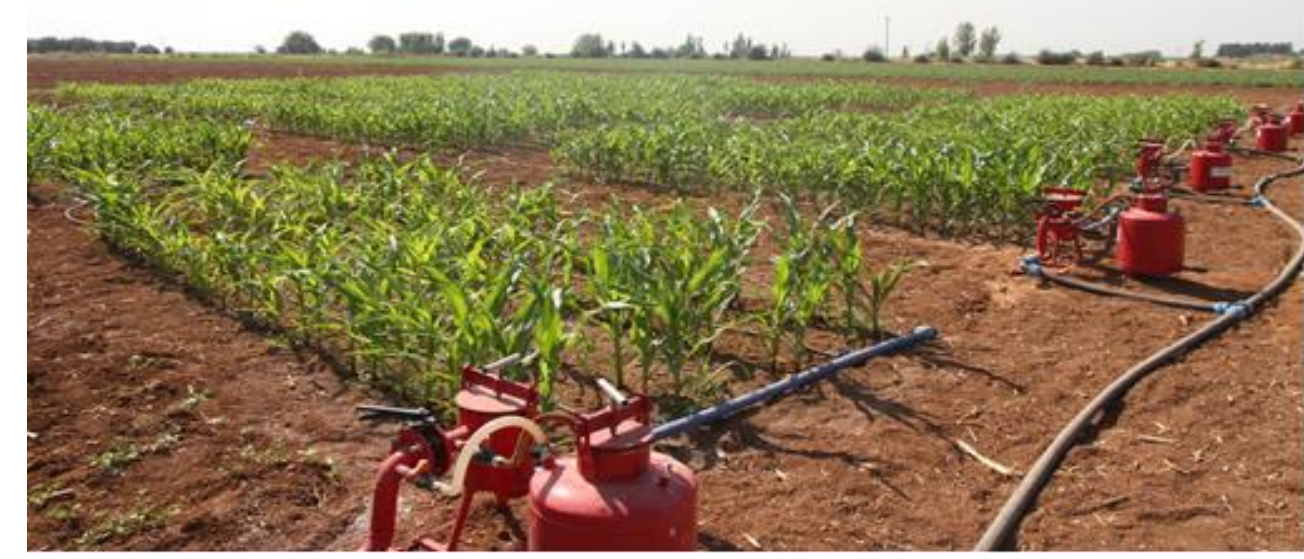

Figure 1. Design of drip irrigation and fertigation system in the reseach area

The equation (Eq.1) given below was used in the calculation of irrigation water (Oktem and Oktem, 2009).

$$
\mathrm{I}=\operatorname{Ep} \times \operatorname{Kcp} \times \mathrm{P} \times \mathrm{A}
$$

In the equality I is the amount of irrigation water (lt), EP is Evaporation from Class APan (mm), Kcp is Pan coefficient (Kcp=1.25), $\mathrm{P}$ is Cover percentage (\%), A represents the parcel area $\left(\mathrm{m}^{2}\right)$.

The following equation (Eq.2) was used in the calculation of the cover percentage (Kanber and Gungor, 1986).

$$
\% \mathrm{P}=\mathrm{a} / \mathrm{b} \times 100
$$

In the equality $\mathrm{a}=$ The width of the projection of the above-ground part of the plant, $\mathrm{b}=$ It represents distance between two plants.

\section{Application of fertilizers}

Fertilization was done considering the soil analysis results of the experimental area. Ten pure nitrogen doses were used in the trial that is $0 \mathrm{~kg} \mathrm{da}^{-1}, 4 \mathrm{~kg} \mathrm{da}^{-1}, 8 \mathrm{~kg} \mathrm{da}^{-1}$, $12 \mathrm{~kg} \mathrm{da}^{-1}, 16 \mathrm{~kg} \mathrm{da}^{-1}, 20 \mathrm{~kg} \mathrm{da}^{-1}, 24 \mathrm{~kg} \mathrm{da}^{-1}, 28 \mathrm{~kg} \mathrm{da}^{-1}, 32 \mathrm{~kg} \mathrm{da}^{-1}$ and $36 \mathrm{~kg} \mathrm{da}^{-1}$ $\left(1 \mathrm{da}=1000 \mathrm{~m}^{2}\right)$. The total nitrogen doses were divided into 10 equal parts considering vegetation period of used variety and given with the drip irrigation system until the end of tasselling period. Nitrogen was given according to BBCH scale from phenological growth stage 1(13) to 5(59) (Lancashire et al., 1991). 1/10 of the total amount of pure nitrogen to be given and the whole amount of pure phosphorus $\left(10 \mathrm{~kg}_{2} \mathrm{O}_{5} \mathrm{da}^{-1}\right)$ were given at once with planting. In the experiment, triple super phosphate $\mathrm{CaH}_{4}\left(\mathrm{PO}_{4}\right)_{2} \cdot \mathrm{H}_{2} \mathrm{O}$ $(43-44 \%)$ fertilizers were used as phosphorus source and urea $(46 \% \mathrm{~N})$ fertilizers were used as nitrogen source. In order to prevent the passage of nitrogen, a space of $2.0 \mathrm{~m}$ was left between the plots and $3.0 \mathrm{~m}$ between the blocks. 


\section{Results and discussion}

\section{Plant height (cm)}

It was determined that the effect of nitrogen amount applied at different doses by the fertigation method on plant height was statistically significant $(\mathrm{P} \leq 0.01)$. The plant height values in 2018, 2019 and the average of the two years of the study varied between $170.75-270.38 \mathrm{~cm}, 179.60-284.60 \mathrm{~cm}$ and $175.18-277.49 \mathrm{~cm}$, respectively (Table 3). In both experimental years, the lowest plant height was obtained from the N0 application, and the highest plant height was obtained from the N28 application (Fig. 2). Although genetic factors affect plant height (Oktem and Oktem, 2013), in parallel with our findings, some researchers reported that plant height increased depending on nitrogen applications (Oktem, 2008b; Cerny et al., 2012; Ullah et al., 2015; Avsar et al., 2018).

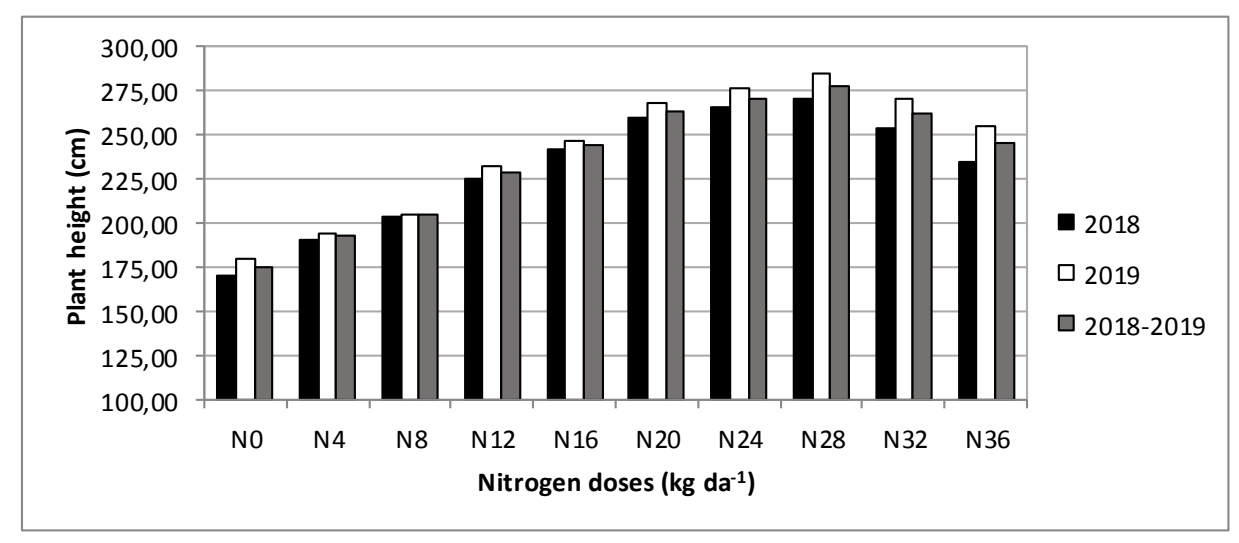

Figure 2. Plant height values at different nitrogen doses given by fertigation method

Table 3. Plant height and stem diameter values at different nitrogen doses given by fertigation method

\begin{tabular}{c|c|c|c|c|c|c}
\hline \multirow{2}{*}{$\begin{array}{c}\text { N Doses } \\
\left(\mathbf{k g ~ d a}^{-\mathbf{1}}\right)\end{array}$} & \multicolumn{3}{|c|}{ Plant height**(cm) } & \multicolumn{3}{c}{ Stem diameter** (mm) } \\
\cline { 2 - 7 } & $\mathbf{2 0 1 8}$ & $\mathbf{2 0 1 9}$ & $\mathbf{2 0 1 8 - 2 0 1 9}$ & $\mathbf{2 0 1 8}$ & $\mathbf{2 0 1 9}$ & $\mathbf{2 0 1 8 - 2 0 1 9}$ \\
\hline N0 & $170.75 \mathrm{~g} \dagger$ & $179.60 \mathrm{~g}$ & $175.19 \mathrm{~g}$ & $10.65 \mathrm{e}$ & $10.85 \mathrm{~g}$ & $10.75 \mathrm{~g}$ \\
$\mathrm{~N} 4$ & $191.00 \mathrm{f}$ & $194.00 \mathrm{f}$ & $192.50 \mathrm{f}$ & $12.65 \mathrm{~d}$ & $12.80 \mathrm{f}$ & $12.73 \mathrm{f}$ \\
N8 & $204.13 \mathrm{e}$ & $205.50 \mathrm{f}$ & $204.81 \mathrm{e}$ & $15.03 \mathrm{c}$ & $14.80 \mathrm{e}$ & $14.91 \mathrm{e}$ \\
N12 & $225.25 \mathrm{~d}$ & $232.30 \mathrm{e}$ & $228.75 \mathrm{~d}$ & $15.88 \mathrm{c}$ & $15.95 \mathrm{~d}$ & $15.91 \mathrm{~d}$ \\
N16 & $242.50 \mathrm{c}$ & $246.30 \mathrm{~d}$ & $244.38 \mathrm{c}$ & $15.78 \mathrm{c}$ & $16.05 \mathrm{~d}$ & $15.91 \mathrm{~d}$ \\
N20 & $260.25 \mathrm{ab}$ & $267.60 \mathrm{bc}$ & $263.94 \mathrm{~b}$ & $19.18 \mathrm{ab}$ & $19.55 \mathrm{~b}$ & $19.36 \mathrm{~b}$ \\
N24 & $265.75 \mathrm{a}$ & $276.10 \mathrm{ab}$ & $270.94 \mathrm{ab}$ & $20.08 \mathrm{a}$ & $20.48 \mathrm{a}$ & $20.28 \mathrm{a}$ \\
N28 & $270.38 \mathrm{a}$ & $284.60 \mathrm{a}$ & $277.50 \mathrm{a}$ & $20.10 \mathrm{a}$ & $20.45 \mathrm{a}$ & $20.28 \mathrm{a}$ \\
N32 & $253.75 \mathrm{~b}$ & $271.10 \mathrm{ab}$ & $262.44 \mathrm{~b}$ & $17.95 \mathrm{~b}$ & $18.63 \mathrm{c}$ & $18.29 \mathrm{c}$ \\
N36 & $235.13 \mathrm{c}$ & $255.40 \mathrm{~cd}$ & $245.25 \mathrm{c}$ & $12.98 \mathrm{~d}$ & $13.28 \mathrm{f}$ & $13.13 \mathrm{f}$ \\
\hline Mean & 231.89 & 241.25 & 236.57 & 16.03 & 16.28 & 16.15 \\
CV & 1.55 & 1.97 & 1.55 & 3.02 & 1.61 & 2.31 \\
\hline
\end{tabular}

$\dagger$ : There is no significant difference at 0.05 level between the averages shown in the same letter according to Duncan test, **: denotes $\mathrm{P} \leq 0.01$ 


\section{Stem diameter $(\mathrm{mm})$}

According to the results of analysis of variance, the effect of different nitrogen doses applied by fertigation method on stem diameter was found to be statistically significant $(\mathrm{P} \leq 0.01)$. It was observed that the stem diameter varied between $10.65 \mathrm{~mm}(\mathrm{~N} 0)$ and $20.10 \mathrm{~mm}$ (N28) in 2018, and between $10.85 \mathrm{~mm}$ (N0) and $20.48 \mathrm{~mm}$ (N24) in 2019 (Table 3). According to the combined analysis results of two years; stem diameter ranged from 10.75 to $20.28 \mathrm{~mm}$ (Fig. 3). The lowest stem diameter was obtained from the N0 application $(10.75 \mathrm{~mm})$, and the highest stem diameter $(20.28 \mathrm{~mm})$ was obtained from the N28 application (Table 4). Similar to our results, it has been reported that stem thickness increases depending on nitrogen applications (Oktem and Oktem, 2005; Kara, 2006; K1lınc et al., 2018; Kahriman et al., 2020).

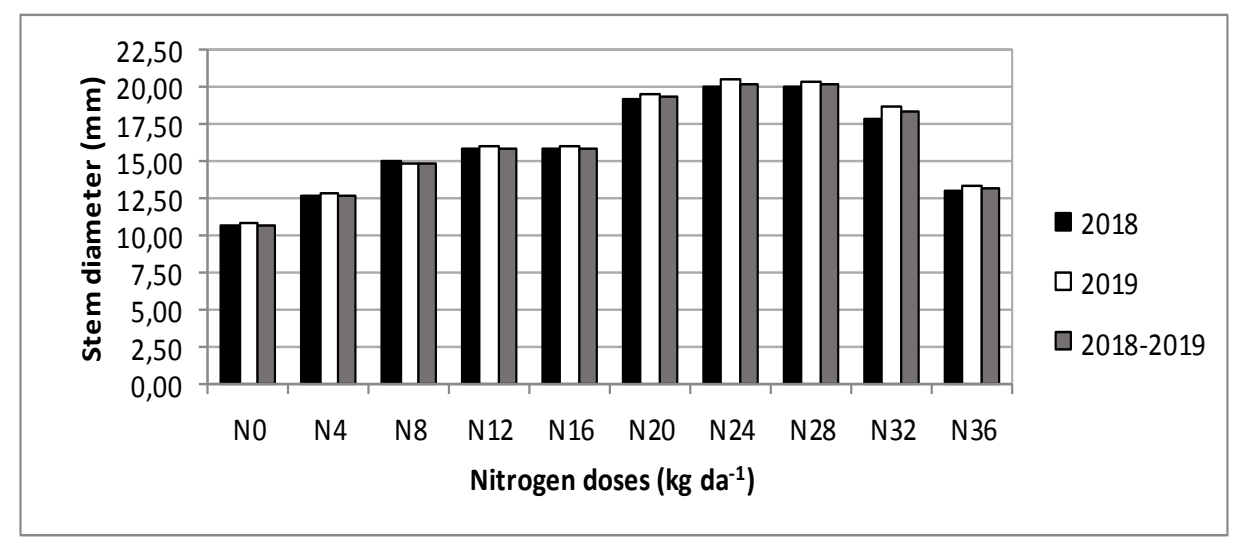

Figure 3. Stem diameter values at different nitrogen doses given by fertigation method

Table 4. Ear length and ear diameter values at different nitrogen doses given by fertigation method

\begin{tabular}{c|c|c|c|c|c|c}
\hline \multirow{2}{*}{$\begin{array}{c}\text { N doses } \\
\left(\text { kg da }^{-1}\right)\end{array}$} & \multicolumn{3}{|c|}{ Ear length** (mm) } & \multicolumn{3}{c}{ Ear diameter** (mm) } \\
\cline { 2 - 7 } N0 & $\mathbf{2 0 1 8}$ & $\mathbf{2 0 1 9}$ & $\mathbf{2 0 1 8 - 2 0 1 9}$ & $\mathbf{2 0 1 8}$ & $\mathbf{2 0 1 9}$ & $\mathbf{2 0 1 8 - 2 0}$ \\
N4 & $7.05 \mathrm{h \dagger}$ & $6.93 \mathrm{i}$ & $6.99 \mathrm{i}$ & $34.53 \mathrm{e}$ & $33.90 \mathrm{~g}$ & $34.22 \mathrm{f}$ \\
N8 & $8.53 \mathrm{~g}$ & 8.401 & $8.47 \mathrm{1}$ & $36.25 \mathrm{e}$ & $36.15 \mathrm{f}$ & $36.20 \mathrm{e}$ \\
N12 & $12.13 \mathrm{f}$ & $10.90 \mathrm{~h}$ & $11.52 \mathrm{~h}$ & $41.23 \mathrm{~d}$ & $41.73 \mathrm{e}$ & $41.48 \mathrm{~d}$ \\
N16 & $13.65 \mathrm{e}$ & $12.48 \mathrm{~g}$ & $13.07 \mathrm{~g}$ & $42.75 \mathrm{~cd}$ & $43.68 \mathrm{de}$ & $43.22 \mathrm{c}$ \\
N20 & $14.68 \mathrm{~d}$ & $14.88 \mathrm{e}$ & $14.78 \mathrm{e}$ & $43.85 \mathrm{c}$ & $43.85 \mathrm{de}$ & $43.85 \mathrm{c}$ \\
N24 & $16.85 \mathrm{c}$ & $16.45 \mathrm{~d}$ & $16.65 \mathrm{~d}$ & $47.78 \mathrm{~b}$ & $47.95 \mathrm{ab}$ & $47.87 \mathrm{~b}$ \\
N28 & $18.68 \mathrm{~b}$ & $18.90 \mathrm{~b}$ & $18.79 \mathrm{~b}$ & $48.50 \mathrm{ab}$ & $49.33 \mathrm{ab}$ & $48.92 \mathrm{ab}$ \\
N32 & $20.88 \mathrm{a}$ & $21.45 \mathrm{a}$ & $21.17 \mathrm{a}$ & $50.60 \mathrm{a}$ & $50.73 \mathrm{a}$ & $50.67 \mathrm{a}$ \\
N36 & $17.60 \mathrm{bc}$ & $17.60 \mathrm{c}$ & $17.60 \mathrm{c}$ & $46.68 \mathrm{ab}$ & $47.65 \mathrm{bc}$ & $47.17 \mathrm{~b}$ \\
Mean & $14.03 \mathrm{de}$ & $13.98 \mathrm{f}$ & $14.01 \mathrm{f}$ & $44.18 \mathrm{c}$ & $45.23 \mathrm{~cd}$ & $44.71 \mathrm{c}$ \\
CV & 7.05 & 6.93 & 6.99 & 43.64 & 44.02 & 43.83 \\
\hline
\end{tabular}

$\dagger$ : There is no significant difference at 0.05 level between the averages shown in the same letter according to Duncan test, **: denotes $\mathrm{P} \leq 0.01$ 


\section{Ear length (cm)}

The effect of different nitrogen doses applied by fertigation method on ear length was determined to be statistically significant $(\mathrm{P} \leq 0.01)$. In 2018, 2019 and the average of the two years, the ear lengths varied between 7.05 and $20.88 \mathrm{~cm}, 6.93$ and $21.45 \mathrm{~cm}$ and 6.99 and $21.17 \mathrm{~cm}$, respectively (Fig. 4).

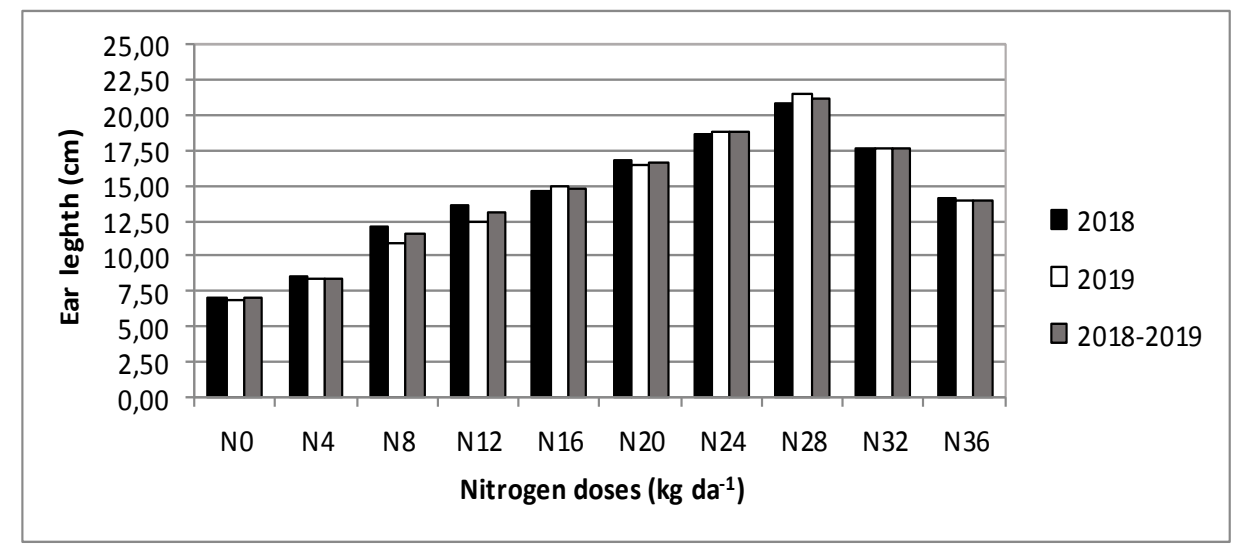

Figure 4. Ear length values at different nitrogen doses given by fertigation method

In both trial years, the lowest ear length was obtained from the N0 application, and the highest ear length was obtained from the N28 application (Table 4). Similar to our findings, it has been reported by some researchers that as the nitrogen dose increases, the ear length increases (Saruhan and Sireli, 2005; Oktem and Oktem, 2005; Kara, 2006; Oktem, 2008b; Safdarian et al., 2014).

\section{Ear diameter (mm)}

The effect of different nitrogen doses on ear diameter in corn plant grown by fertigation method was found to be statistically significant $(\mathrm{P} \leq 0.01)$. According to 2018 values, the lowest ear diameter was obtained from the N0 subject $(34.53 \mathrm{~mm})$, and the highest ear diameter was obtained from the $\mathrm{N} 28$ subject $(50.60 \mathrm{~mm})$. Ear diameter varied between $33.90 \mathrm{~mm}$ (N0) and $50.73 \mathrm{~mm} \mathrm{~N} 28$ in the 2019 growing season (Table 4).

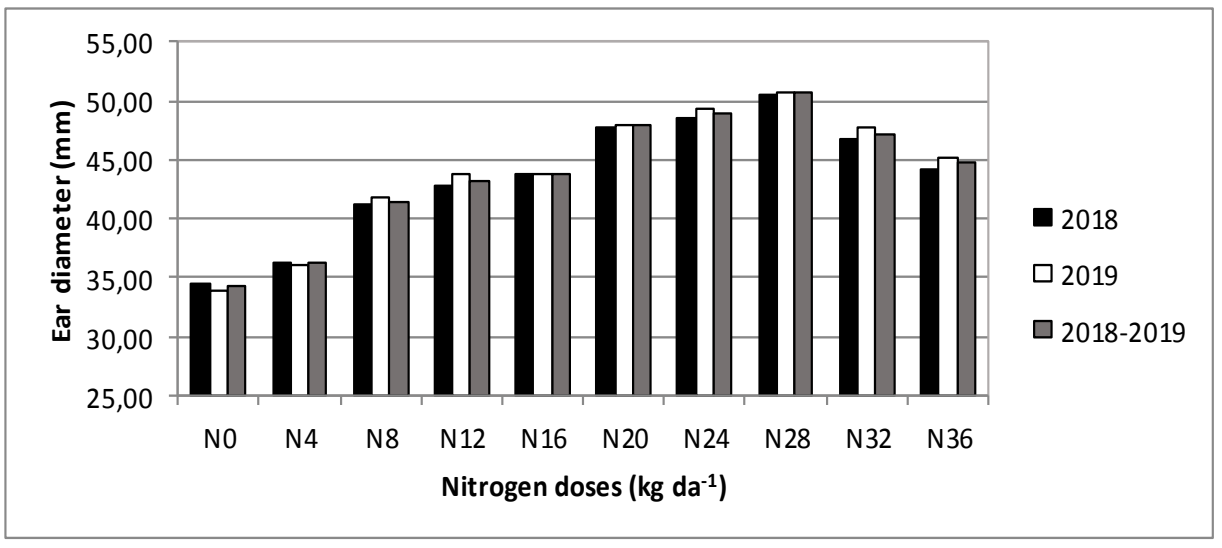

Figure 5. Ear diameter values at different nitrogen doses given by fertigation method 
According to the average of two years; the lowest ear diameter was found in N0 $(34.22 \mathrm{~mm})$, and the highest ear diameter $(50.67 \mathrm{~mm})$ was found in N28 (Fig. 5). In parallel with the increase in nitrogen doses, the ear diameter values also increased. Some researchers have stated in their studies that the ear diameter increases depending on the increased nitrogen doses (Saruhan and Sireli, 2005; Kara, 2006; Oktem, 2008b; Can and Akman, 2014).

\section{Thousand kernel weight (g)}

The effect of different nitrogen amounts on thousand kernel weight in corn plant was found to be statistically significant $(\mathrm{P} \leq 0.01)$. According to the 2018 values of the study, it was observed that the thousand-kernel weight varied between $274 \mathrm{~g}$ and $319 \mathrm{~g}$, and in the 2019 growing season, it varied between $309 \mathrm{~g}$ and $373 \mathrm{~g}$ (Table 5).

Table 5. Thousand kernel weight and grain yield values at different nitrogen doses given by fertigation method

\begin{tabular}{c|c|c|c|c|c|c}
\hline \multirow{2}{*}{$\begin{array}{c}\text { N doses } \\
\left(\text { kg da }^{-1}\right)\end{array}$} & \multicolumn{2}{|c|}{ Thousand kernel weight**(g) } & \multicolumn{3}{c}{ Grain yield** $^{*}\left(\mathbf{k g ~ d a}^{\mathbf{- 1}}\right)$} \\
\cline { 2 - 7 } & $\mathbf{2 0 1 8}$ & $\mathbf{2 0 1 9}$ & $\mathbf{2 0 1 8 - 2 0 1 9}$ & $\mathbf{2 0 1 8}$ & $\mathbf{2 0 1 9}$ & $\mathbf{2 0 1 8 - 2 0 1 9}$ \\
\hline N0 & $310 \mathrm{ab}$ & $309 \mathrm{~d} \dagger$ & $310 \mathrm{c}$ & $315 \mathrm{~h}$ & $553 \mathrm{~h}$ & $434 \mathrm{f}$ \\
N4 & $299 \mathrm{abc}$ & $333 \mathrm{c}$ & $316 \mathrm{c}$ & $610 \mathrm{~g}$ & $846 \mathrm{~g}$ & $728 \mathrm{e}$ \\
N8 & $274 \mathrm{c}$ & $344 \mathrm{bc}$ & $309 \mathrm{c}$ & $892 \mathrm{f}$ & $1047 \mathrm{f}$ & $970 \mathrm{~d}$ \\
N12 & $297 \mathrm{abc}$ & $331 \mathrm{c}$ & $314 \mathrm{c}$ & $1074 \mathrm{e}$ & $1189 \mathrm{e}$ & $1132 \mathrm{c}$ \\
N16 & $300 \mathrm{abc}$ & $339 \mathrm{bc}$ & $320 \mathrm{bc}$ & $1229 \mathrm{c}$ & $1331 \mathrm{~d}$ & $1280 \mathrm{~b}$ \\
N20 & $305 \mathrm{ab}$ & $349 \mathrm{~b}$ & $327 \mathrm{abc}$ & $1301 \mathrm{bc}$ & $1393 \mathrm{c}$ & $1347 \mathrm{~b}$ \\
N24 & $315 \mathrm{a}$ & $369 \mathrm{a}$ & $342 \mathrm{ab}$ & $1428 \mathrm{ab}$ & $1499 \mathrm{~b}$ & $1464 \mathrm{a}$ \\
N28 & $319 \mathrm{a}$ & $373 \mathrm{a}$ & $346 \mathrm{a}$ & $1567 \mathrm{a}$ & $1621 \mathrm{a}$ & $1594 \mathrm{a}$ \\
N32 & $297 \mathrm{ab}$ & $370 \mathrm{a}$ & $334 \mathrm{abc}$ & $1201 \mathrm{~cd}$ & $1351 \mathrm{~cd}$ & $1276 \mathrm{~b}$ \\
N36 & $289 \mathrm{bc}$ & $369 \mathrm{a}$ & $329 \mathrm{abc}$ & $1106 \mathrm{de}$ & $1105 \mathrm{f}$ & $1106 \mathrm{c}$ \\
Mean & 301 & 349 & 325 & 1072 & 1194 & 1133 \\
CV & 6.36 & 1.75 & 4.45 & 5.60 & 3.46 & 3.83 \\
\hline
\end{tabular}

$\dagger$ : There is no significant difference at 0.05 level between the averages shown in the same letter according to Duncan test, **: denotes $\mathrm{P} \leq 0.01$

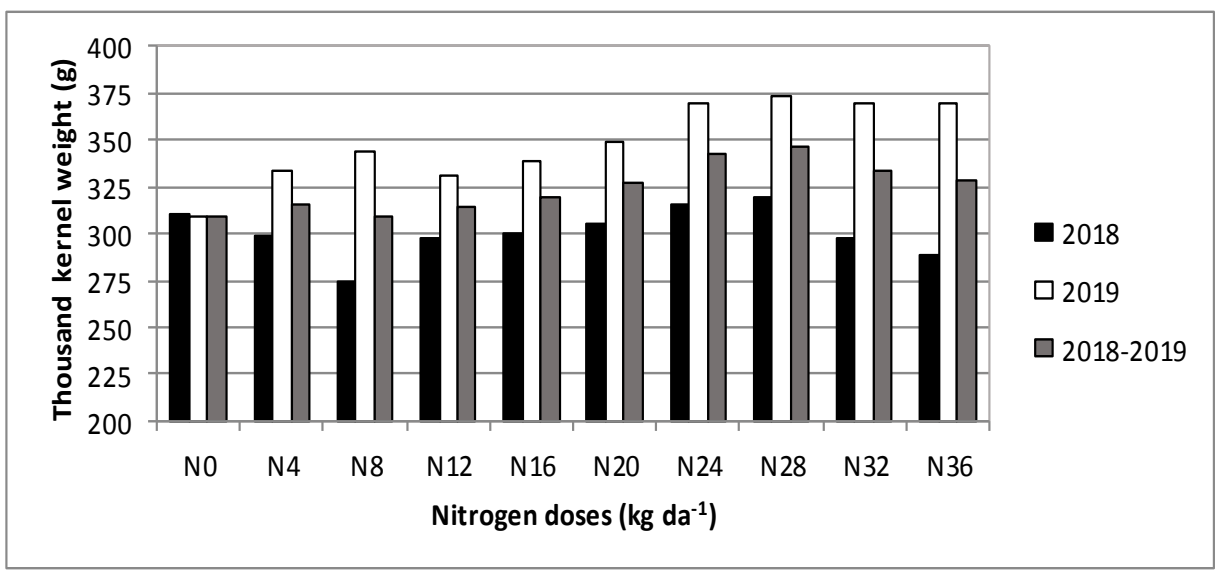

Figure 6. Thousand kernel weight values at different nitrogen doses given by fertigation 
According to the combined analysis results of two years; the thousand kernel weights varied between $310 \mathrm{~g}$ and $346 \mathrm{~g}$ in different $\mathrm{N}$ treatments. Increasing nitrogen doses had a positive effect on the grain weight (Fig. 6). Some researchers reported that the thousand kernel weight increased with increasing nitrogen doses and reported similar results with our findings (Amaral et al., 2005; Kara, 2006; Yururdurmaz, 2007).

\section{Grain yield $\left(\mathrm{kg} \mathrm{da}^{-1}\right)$}

According to the results of analysis of variance, it was determined that the effect of different nitrogen doses given by fertigation method on grain yield was statistically significant $(\mathrm{P} \leq 0.01)$. In 2018, 2019 and the average of the two years of the research, it was observed that the grain yield values changed between 315 and $1567 \mathrm{~kg} \mathrm{da}^{-1}$, between 553 and $1621 \mathrm{~kg} \mathrm{da}^{-1}$, and between 434 and $1594 \mathrm{~kg} \mathrm{da}^{-1}$, respectively. In both trial years, the lowest grain yield was found in N0 application and the highest grain yield was found in N28 application (Table 5). But N24 and N28 applications were in the same statistical group at means of years. As the amount of nitrogen increased, the grain yield increased up to $28 \mathrm{~kg} \mathrm{da}^{-1}$ nitrogen dose, after which a decrease was observed.

Increasing nitrogen doses had a positive effect on grain yield (Fig. 7). The nitrogen use efficiency can vary according to genotypes. Supporting our findings, some researchers stated that grain yield increased in response to increasing nitrogen dose (Allen et al., 2000; Oktem et al., 2001, 2010; Blumental et al., 2003; Tunalı et al., 2012; Yolcu, 2014; Avsar et al., 2018; Koca and Ibrikci, 2019). A significant second order polynomial relationship was found between grain yield and nitrogen doses in average of both years as shown in Fig. $7(\mathrm{P} \leq 0.01)$. The relationship equation was $\mathrm{y}=-28.831 \mathrm{x}^{2}+402.39 \mathrm{x}+$ $29.775\left(\mathrm{R}^{2}=0.9529\right)$. From the regression analysis $($ Fig. 7$)$, it seems appropriate to give $24 \mathrm{~kg} \mathrm{da}^{-1}$ nitrogen to corn by fertigation method.

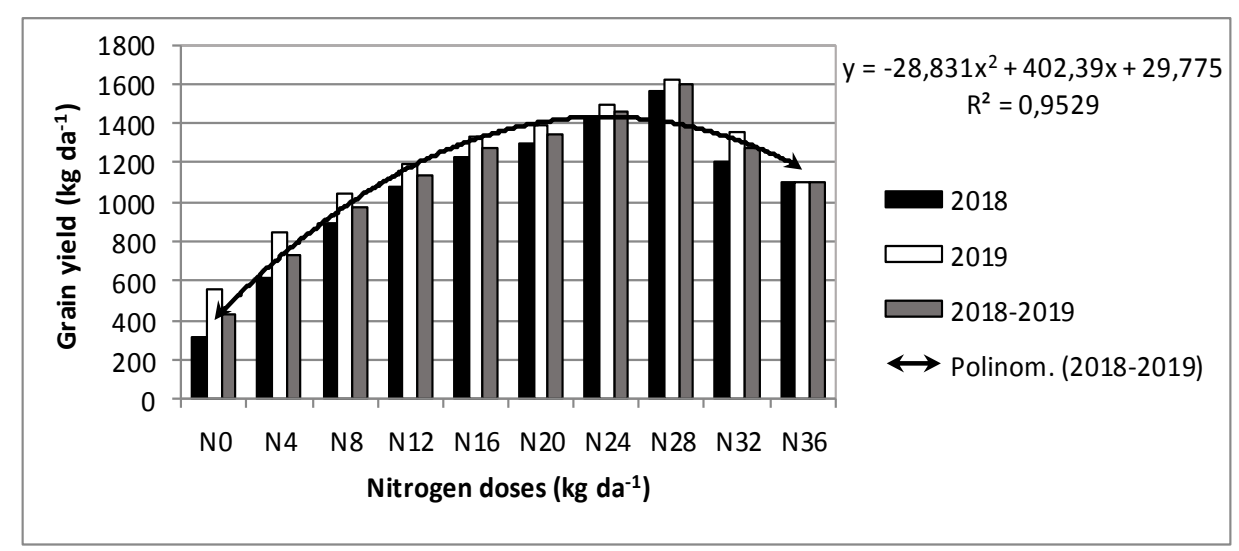

Figure 7. Gain yield values at different nitrogen doses given by fertigation method

\section{Leaf area of plant $\left(\mathrm{cm}^{2}\right.$ bitki $\left.^{-1}\right)$}

The effect of different nitrogen amounts on the leaf area of the plant was found to be statistically significant $(\mathrm{P} \leq 0.01)$. In the 2018 trial year, the leaf area per plant varied between $108 \mathrm{~cm}^{2}$ plant $^{-1}$ (N0) and $613 \mathrm{~cm}^{2}$ plant $^{-1}$ (N28). In 2019, the lowest leaf area was taken from the N0 application $\left(116 \mathrm{~cm}^{2}\right.$ plant $\left.{ }^{-1}\right)$, and the highest plant $\left(629 \mathrm{~cm}^{2}\right.$ plant $\left.^{-1}\right)$ was taken from the $\mathrm{N} 28$ application (Table 6). 
Table 6. Leaf area and protein content of kernel values at different nitrogen doses given by fertigation method

\begin{tabular}{|c|c|c|c|c|c|c|}
\hline \multirow{2}{*}{$\begin{array}{l}\text { N doses } \\
\left(\mathrm{kg} \mathrm{da}^{-1}\right)\end{array}$} & \multicolumn{3}{|c|}{ Leaf area $^{* *}\left(\mathrm{~cm}^{2}\right.$ plant $\left.^{-1}\right)$} & \multicolumn{3}{|c|}{ Protein content $* *(\%)$} \\
\hline & 2018 & 2018 & 2018-2019 & 2018 & 2019 & 2018-2019 \\
\hline No & $108 \mathrm{f \dagger}$ & $116 \mathrm{~g}$ & $112 \mathrm{~g}$ & $7.48 \mathrm{~b}$ & $7.30 \mathrm{~b}$ & $7.39 \mathrm{~b}$ \\
\hline N4 & $151 \mathrm{ef}$ & $158 \mathrm{f}$ & $154 \mathrm{f}$ & $8.03 \mathrm{ab}$ & $7.95 \mathrm{ab}$ & $7.99 \mathrm{ab}$ \\
\hline N8 & $170 \mathrm{e}$ & $176 \mathrm{f}$ & $173 \mathrm{f}$ & $8.20 \mathrm{ab}$ & $8.03 \mathrm{ab}$ & $8.11 \mathrm{ab}$ \\
\hline N12 & $231 \mathrm{~d}$ & $251 \mathrm{e}$ & $241 \mathrm{e}$ & $8.23 \mathrm{ab}$ & $8.10 \mathrm{ab}$ & $8.16 \mathrm{ab}$ \\
\hline N16 & $308 \mathrm{c}$ & $324 \mathrm{~d}$ & $316 \mathrm{~d}$ & $8.28 \mathrm{ab}$ & $8.13 \mathrm{ab}$ & $8.20 \mathrm{ab}$ \\
\hline $\mathrm{N} 20$ & $416 \mathrm{~b}$ & $457 \mathrm{~b}$ & $436 \mathrm{~b}$ & $8.70 \mathrm{ab}$ & $8.20 \mathrm{ab}$ & $8.45 \mathrm{ab}$ \\
\hline $\mathrm{N} 24$ & $547 \mathrm{a}$ & $566 \mathrm{a}$ & $557 \mathrm{a}$ & $8.85 \mathrm{ab}$ & $8.35 \mathrm{ab}$ & $8.60 \mathrm{a}$ \\
\hline N28 & $613 \mathrm{a}$ & $629 a$ & $621 \mathrm{a}$ & $8.88 \mathrm{a}$ & $8.80 \mathrm{a}$ & $8.84 \mathrm{a}$ \\
\hline N32 & $370 \mathrm{~b}$ & $400 \mathrm{c}$ & $385 \mathrm{c}$ & $8.83 \mathrm{ab}$ & $8.43 \mathrm{ab}$ & $8.63 \mathrm{a}$ \\
\hline N36 & $227 \mathrm{~d}$ & $244 \mathrm{e}$ & $236 \mathrm{e}$ & $8.73 \mathrm{ab}$ & $8.38 \mathrm{ab}$ & $8.55 \mathrm{a}$ \\
\hline Mean & 314 & 332 & 323 & 8.42 & 8.17 & 8.29 \\
\hline $\mathrm{CV}$ & 3.91 & 2.31 & 3.22 & 4.00 & 4.00 & 4.00 \\
\hline
\end{tabular}

$\dagger$ : There is no significant difference at 0.05 level between the averages shown in the same letter according to Duncan test, ${ }^{* *}$ : denotes $\mathrm{P} \leq 0.01$

According to the combined analysis results of two years, it was observed that the leaf area per plant varied between $112 \mathrm{~cm}^{2}$ plant $^{-1}$ (N0) and $621 \mathrm{~cm}^{2}$ plant $^{-1}$ (N28). Leaf area values increased in parallel with the increase in nitrogen (Fig. 8). Supporting our research findings, some researchers reported that leaf area values increased with increasing nitrogen doses (Yururdurmaz, 2007; Hokmalipour et al., 2011; Tunalı et al., 2012).

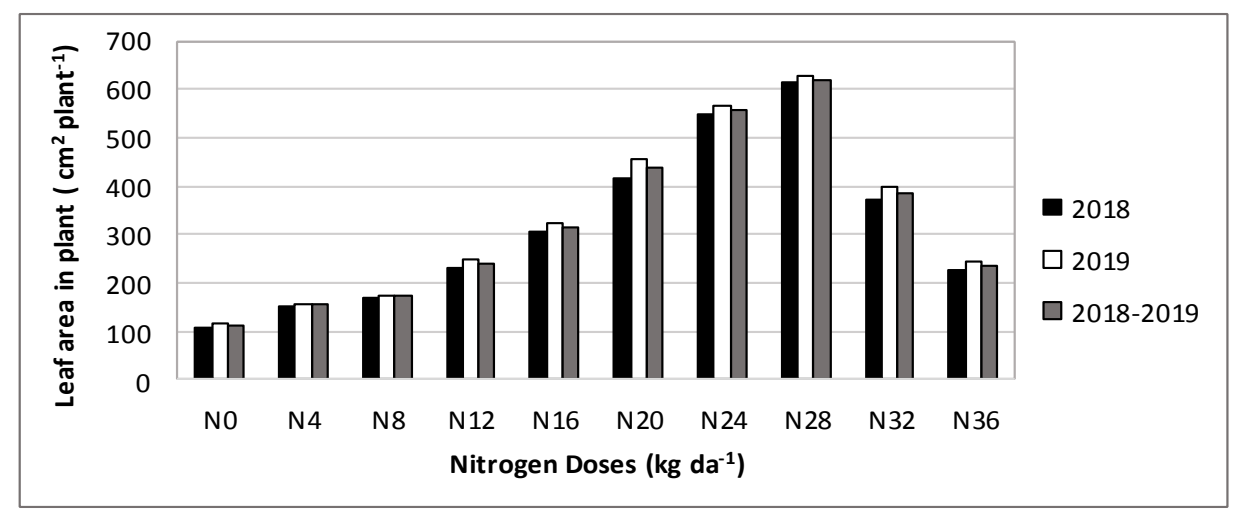

Figure 8. Leaf area in plant values at different nitrogen doses given by fertigation method

\section{Protein content of kernel (\%)}

According to analysis of variance, the effect of different nitrogen amount on kernel protein content was found to be statistically significant $(\mathrm{P} \leq 0.01)$. According to the combined analysis results of two years it was observed that the protein content in the kernel varied between $7.39 \%$ and $8.84 \%$ in different $\mathrm{N}$ applications (Fig. 9). 


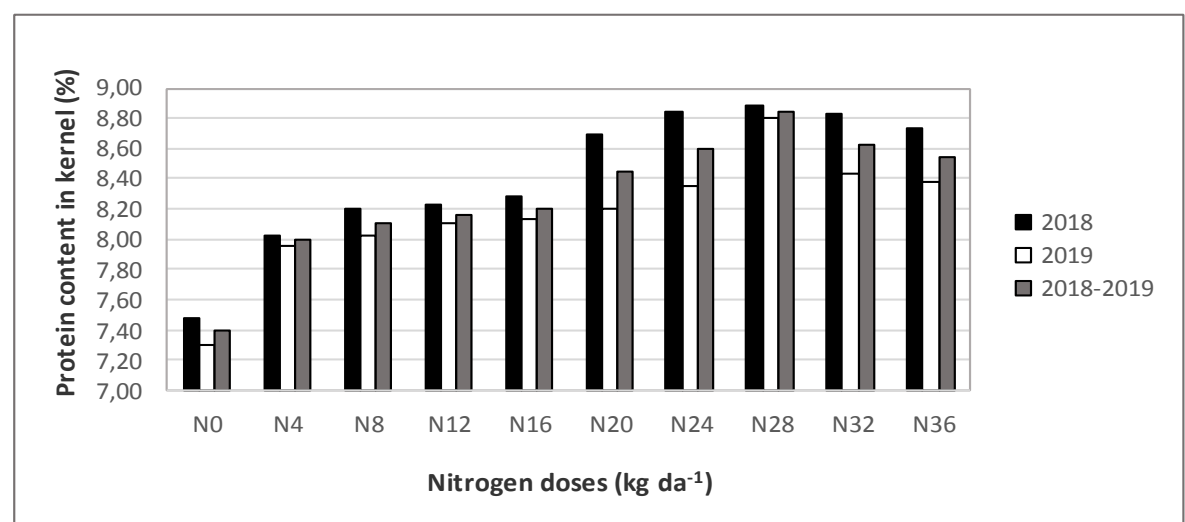

Figure 9. Protein content of kernel values at different nitrogen doses given by fertigation

The lowest kernel protein content was obtained from N0 application, and the highest kernel protein content $(8.84 \%$ ) was obtained from N28 application (Table 6). Parallel to our findings, some researchers stated that the protein ratio increased as the nitrogen dose increased (Patricio Soto et al., 2004; Oktem, 2008c; Oktem et al., 2010; Ullah et al., 2015; Avsar et al., 2018; K1lınc et al., 2018; Kahriman et al., 2020). Ozsisli (2010), on the other hand, reported higher protein content values than our findings.

\section{Starch content of kernel (\%)}

The effect of different nitrogen amount applied by fertigation method on starch content in kernel was not found statistically significant. According to the combined analysis results of two years; the starch content in kernels varied between $70.90 \%$ and $71.62 \%$. The lowest starch content in the kernel was obtained from the N36 application $(70.90 \%)$, and the highest starch content in the kernel $(71.62 \%)$ was obtained from the N8 application (Table 7).

Table 7. Starch and oil content of kernel values at different nitrogen doses given by fertigation method

\begin{tabular}{|c|c|c|c|c|c|c|}
\hline \multirow{2}{*}{$\begin{array}{l}\text { N Doses } \\
\left(k \text { da }^{-1}\right)\end{array}$} & \multicolumn{3}{|c|}{ Starch content $* *(\%)$} & \multicolumn{3}{|c|}{ Oil content $* *(\%)$} \\
\hline & 2018 & 2019 & 2018-2019 & 2018 & 2019 & 2018-2019 \\
\hline No & 69.68 & 72.80 & 71.24 & $4.15 \mathrm{~b} \dagger$ & $4.25 \mathrm{~b}$ & $4.20 \mathrm{c}$ \\
\hline N4 & 70.58 & 72.08 & 71.33 & $4.25 \mathrm{ab}$ & $4.35 \mathrm{ab}$ & $4.30 \mathrm{bc}$ \\
\hline N8 & 70.95 & 72.28 & 71.62 & $4.35 \mathrm{ab}$ & $4.40 \mathrm{ab}$ & $4.38 \mathrm{abc}$ \\
\hline N12 & 70.85 & 72.05 & 71.45 & $4.43 \mathrm{ab}$ & $4.48 \mathrm{ab}$ & $4.45 \mathrm{abc}$ \\
\hline N16 & 70.85 & 72.25 & 71.55 & $4.45 \mathrm{ab}$ & $4.48 \mathrm{ab}$ & $4.46 \mathrm{abc}$ \\
\hline $\mathrm{N} 20$ & 70.48 & 72.15 & 71.32 & $4.48 \mathrm{ab}$ & $4.50 \mathrm{ab}$ & $4.49 \mathrm{ab}$ \\
\hline N24 & 70.48 & 71.60 & 71.04 & $4.55 \mathrm{a}$ & $4.60 \mathrm{ab}$ & $4.58 \mathrm{ab}$ \\
\hline $\mathrm{N} 28$ & 69.90 & 72.05 & 70.98 & $4.59 \mathrm{a}$ & $4.73 \mathrm{a}$ & $4.66 \mathrm{a}$ \\
\hline N32 & 70.88 & 71.95 & 71.42 & $4.48 \mathrm{ab}$ & $4.55 \mathrm{ab}$ & $4.51 \mathrm{ab}$ \\
\hline N36 & 70.45 & 71.35 & 70.90 & $4.48 \mathrm{ab}$ & $4.55 \mathrm{ab}$ & $4.51 \mathrm{ab}$ \\
\hline Mean & 70.51 & 72.06 & 71.28 & 4.42 & 4.49 & 4.45 \\
\hline $\mathrm{CV}$ & 0.97 & 1.16 & 1.06 & 7.65 & 4.23 & 6.36 \\
\hline
\end{tabular}

$\dagger$ : There is no significant difference at 0.05 level between the averages shown in the same letter according to Duncan test, **: denotes $\mathrm{P} \leq 0.01$ 
In parallel with our findings, similar starch content values in maize have been reported by some researchers (Ignjatovic-Micic et al., 2014; Kahriman et al., 2020). Some other researchers reported lower starch content values than our findings (Ozsisli, 2010; Kilınc et al., 2018).

\section{Oil content of kernel (\%)}

According to the analysis of variance, it was determined that the effect of different nitrogen amounts applied by fertigation method on the oil content in the grain was statistically significant $(\mathrm{P} \leq 0.01)$. According to the values of the first year of the study, the lowest oil content in the grain was obtained from the N0 application (4.15\%), and the highest oil content in the grain (4.59\%) was obtained from the N28 application.

It was observed that the oil content in the grain varied between $4.25 \%$ (N0) and $4.73 \%$ (N28) in the 2019 growing season (Table 7). According to the combined analysis results of two years; the lowest oil content in the kernel was taken from the N0 application (4.20\%), and the highest kernel oil content $(4.66 \%)$ was taken from the N28 application. It has been reported that the oil content of the corn kernel is 4.3\% (Watson, 2003). Josipovic et al. (2014) reported that grain oil ratios ranged from 3.50 to $4.17 \%$.

The oil content in the kernel increased from N0 application to N28 application (Fig. 10). Increasing nitrogen doses had a positive effect on grain oil content. It has also been stated in previous studies that nitrogen doses have a positive effect on grain oil content (Paiva et al., 2011; Ignjatovic-Micic et al., 2014; Ozata and Kapar, 2014; Avsar et al., 2018; Kahriman et al., 2020).

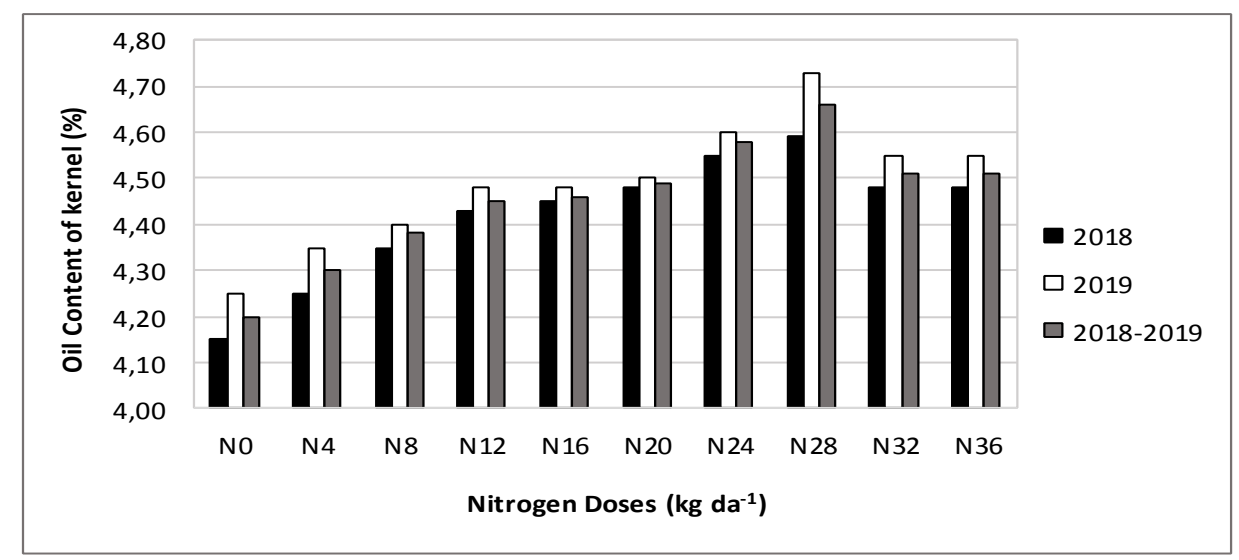

Figure 10. Oil content of kernel values at different nitrogen doses given by fertigation

\section{Conclusion}

As a result of this study which was carried out to determine the most appropriate nitrogen amount by fertigation method, according to the average of two years; plant height ranged from 175.18 to $277.49 \mathrm{~cm}$, stem diameter 10.75 to $20.28 \mathrm{~mm}$. Ear length varied from 6.99 to $21.17 \mathrm{~mm}$, ear thickness 34.22 to $50.67 \mathrm{~mm}$. Thousand kernel weight ranged from 309 to $373 \mathrm{~g}$, grain yield from 434 to $1594 \mathrm{~kg} \mathrm{da}^{-1}$. The leaf area per plant was between $112 \mathrm{~cm}^{2}$ plant $^{-1}$ and $621 \mathrm{~cm}^{2}$ plant $^{-1}$, the protein content in the kernel was between $7.39 \%$ and $8.84 \%$. The starch content was found between $70.90 \%$ and $71.62 \%$, and the oil content in the kernel varied between $4.20 \%$ and $4.66 \%$. The analyzed parameters were found to be statistically significant $(\mathrm{P}<0.01)$. In general, an increase was 
recorded in the properties examined from the N0 application to the N28 application, but a decrease was observed after N28 nitrogen dose. The nitrogen doses applied by the fertigation method had a positive effect on the investigated properties. According to twoyears average, the highest grain yield was determined in $28 \mathrm{~kg} \mathrm{da}^{-1}$ nitrogen application with fertigation system. But there were no statistical differences between N24 and N28 applications. When factors such as economic factors, protection of natural resources, environmental pollution, sustainable agriculture, and regression analysis (Fig. 7) are taken into consideration, $24 \mathrm{~kg} \mathrm{da}^{-1}$ of nitrogen given by fertigation method seems more appropriate for corn. It is useful to repeat similar fertigation studies with nitrogen for different corn varieties and different locations in the world.

Acknowledgements. The authors are grateful to the Republic of Turkey, and the Ministry of Agriculture and Forestry for financial support. Project No: TAGEM/TSKAD/15/A13/P04/05.

\section{REFERENCES}

[1] Allen, T. H., Potter, K. N., Morrison, J. E. (2000): Tillage system, fertilizer nitrogen rate and timing effect on corn yields in the texas blackland prairie. - Agron. J. 93: 1119-1124.

[2] Amaral, C. P. R., Filho, D. F., Farinelli, R., Barbosa, J. K. (2005): Row spacing. population density and nitrogen fertilization in maize. - Rev. Bras. Cienc. Solo Vicosa 29: 467-473.

[3] Avsar, O., Kolay, B., Bilge, U., Bereketoglu, K., Atakul, S., Yasar, M. (2018): Determination of the effects of different amounts of nitrogen applications by fertigation method on yield and yield parameters of sweet corn. - Project Results Report GAP UTAEM, Diyarbakır, Turkey.

[4] Blumental, J. M., Lyon, D. J., Stroup, W. W. (2003): Optimal plant population and nitrogen fertility for dryland corn in Western Nebraska. - Agronomy Journal 95(4): 878-884.

[5] Can, M., Akman, Z. (2014): The effect of different nitrogen doses on yield and quality characteristics of sweet corn. - Journal of Suleyman Demirel University Faculty of Agriculture 9(2): 93-101.

[6] Cerny, J., Balık, J., Kulhanek, M., Vasak, F., Peklova, L., Sedlar, O. (2012): The effect of mineral $\mathrm{N}$ fertiliser and sewage sludge on yield and nitrogen efficiency of silage maize. Plant Soil Environ 58(2): 76-83.

[7] Cokkızgin, A. (2002): The effect of different nitrogen doses and in-row sowing distances on yield components and physiological characteristics of second crop maize. - KSU Sutçu Imam University, Institute of Science, Master Thesis, K.Maras, Turkey, 73p.

[8] Dinc, U., Senol, S., Satın, M., Kapur, S., Güzel, N., Derici, R. (1988): Southeastern Anatolia soils of Turkey, I. Harran Plain. - TUBITAK, TOAG534, Final Result Report, Ankara, Turkey.

[9] Hokmalipour, S., Hamele Darbendi, M. (2011): Effects of nitrogen fertilizer on chlorophyll content and other leaf indicate in three cultivars of maize (Zea mays L.). - World Applied Sciences Journal 15(12): 1780-1785.

[10] Ignjatovic-Micic, D., Kostadinovic, M., Bozinovic, S., Andjelkovic, V., Vancetovic, J. (2014): High grain quality accessions within a maize drought tolerant core collection. Scientia Agricola 71(5): 402-409.

[11] Josipovic, M., Plavsic, H., Kovacevic, V., Markovic, M., Iljkic D. (2014): Impacts of 1rrigation and genotype on yield, protein, starch and oil contents in grain of maize inbred lines. - Genetika Journal 46(1): 243-253.

[12] Kahriman, F., Ada, F., Uysal, Z., Songur, U. (2020): Investigation of yield and grain quality characteristics of Turkmenistan origin local corn populations. - Canakkale University, Journal of Agricultural Faculty, Special Issue, pp.79-86. 
[13] Kanber, R., Gungor, H. (1986): Use of Open Water Surface (Class A Pan) Evaporation in irrigation programs. - Rural Services, Plant Water Consumption Main Project No. 433, Eskisehir, Turkey, 25p.

[14] Kaplan, M., Aktas, M. (1993): Comparison of the effectiveness of ammonium nitrate and urea fertilizers in hybrid corn and determination of proper nitrogen doses of corn. - Journal of Agriculture and Forestry 17: 649-657.

[15] Kara, B. (2006): Determination of yield and yield characteristics, nitrogen uptake and utilization efficiency of maize at different plant frequencies and nitrogen doses in Çukurova conditions. - Cukurova Univ. Institute of Science, PhD Thesis, Adana, Turkey, 162p.

[16] K1lınc, S., Karademir, C., Ekin, Z. (2018): Determination of yield and quality characteristics of some maize (Zea mays L.) cultivars. - KSU Journal of Agriculture and Nature 21(6): 809-816.

[17] Koca, G., Ibrikci, H. (2019): Nitrogen and yield relations in maize plant in Çukurova conditions. - Cukurova J. Agric. Food Sci. 34(2): 119-125.

[18] Lancashire, P. D., Bleiholder, H., Langelüddecke, P., Stauss, R., Van Den Boom, T., Weber, E., Witzenberger, A. (1991): An uniform decimal code for growth stages of crops and weeds. - Ann. Appl. Biol. 119: 561-601.

[19] Oktem, A., Ulger, A. C., Kırtok, Y. (2001): The effect of different nitrogen doses and row spacing on grain yield and some agronomic traits in popcorn (Zea mays everta Sturt.). Cukurova J. Agric. Food Sci. 16(2): 83-92.

[20] Oktem, A. G., Oktem, A. (2005): Effect of nitrogen and intra row spaces on sweet corn (Zea mays saccharata Sturt) ear characteristics. - Asian Journal of Plant Science 4(4): 361364.

[21] Oktem, A. (2006): Effect of different irrigation intervals to drip irrigated dent corn (Zea mays L. indentata) water-yield relationship. - Pakistan Journal of Biological Sciences 9(8): 1476-1481.

[22] Oktem, A. (2008a): Effect of water shortage on yield, and protein and mineral compositions of drip-irrigated sweet corn in sustainable agricultural systems. - Agricultural Water Management 95(9): 1003-1010.

[23] Oktem, A. (2008b): Effects of deficit irrigation on some yield characteristics of sweet corn. - Bangladesh Journal of Botany 37(2): 127-131.

[24] Oktem, A. (2008c): Effect of nitrogen on fresh ear yield and kernel protein content of sweet corn (Zea mays saccharata) under upper Mesopotamia region of Turkey. - Indian Journal of Agricultural Sciences 78(1): 50-55.

[25] Oktem, A., Oktem, A. G. (2009): Yield characteristics of sweet corn under deficit irrigation in Southeastern Turkey. - The Philippine Agricultural Scientist 92(3): 39-44.

[26] Oktem, A., Oktem, A. G., Emeklier, H. Y. (2010): Effect of nitrogen to yield and some quality parameters of sweet corn. - Communications in Soil Science and Plant Analysis 41(7): 832-847.

[27] Oktem, A., Oktem, A. G. (2013): Determination of effective characteristics to green plant yield of corn as a selection criterion. - Soil-Water Journal 2(2): 1625-1632.

[28] Oktem, A. G., Oktem, A. (2020a): Effect of farmyard manure application on yield and some quality characteristics of popcorn (Zea mays L. everta Sturt) at the organic farming. - Journal of Agriculture and Ecology Research International 21(9): 35-42.

[29] Oktem, A. G., Oktem, A. (2020b): Effect of humic acid application methods on yield and some yield characteristics of corn plant (Zea mays L. indentata). - Journal of Applied Life Sciences International 23(11): 31-37.

[30] Ozata, E., Kapar, H. (2014): Determination of quality and performance of some dent hybrid maize (Zea mays indentata Sturt) genotypes under Samsun conditions. - Journal of Agricultural Sciences Research 7(2): 01-07.

[31] Ozsisli, B. (2010): Investigation of yield and quality characteristics of different corn varieties grown as main and second crop in Kahramanmaras conditions. - KSU Sutcu Imam University, Institute of Science, PhD Thesis, K. Maras, Turkey, 130p. 
[32] Paiva, P., Bezerra de Mello Monte, M. (2011): Yield, quality components, and nitrogen levels of silage corn fertilized with urea and zeolite. - Communications in Soil Science and Plant Analysis 42: 1266-1275.

[33] Patricio Soto, O., Ernesto Jahn, B., Susana Arredondo, S. (2004): Improvement of protein percentage in corn silage with an increase in and partitioning of nitrogen fertilization. Agricultura Tecnia 64(2): 156-162.

[34] Safdarian, M., Razmjoo, J., Movahhedi Dehnavi, M. (2014): Effect of nitrogen sources and rates on yield and quality of silage corn. - Journal of Plant Nutrition 37(4): 611-617.

[35] Saruhan, V., Sireli, H. D. (2005): The effect of different nitrogen doses and plant density on ear, stem and leaf characteristics in maize plant (Zea mays L.). - Journal of Agriculture 9(2): 45-53.

[36] Tunalı, M., Budaklı, M., Carpıcı, E., Celik, N. (2012): The effects of different nitrogen doses on chlorophyll content, leaf area index and grain yield in some corn cultivars. Journal of Agricultural Sciences Research 5(1): 131-133.

[37] Ullah, M. I., Khakwani, A. A., Sadiq, M., Awan, I., Munir, M., Ghazanfarullah, A. (2015): Effects of nitrogen fertilization rates on growth. quality and economic return of fodder maize (Zea mays L.). - Sarhad Journal of Agricul 31(1): 45-52.

[38] Watson, S. A. (2003): Description, development, structure and composition of the corn kernel. - In: White, P. J., Johnson, L. A. (eds.) Corn: chemistry and technology, $2^{\text {nd }}$ ed. American Association of Cereal Chemists, St. Paul, MN, USA. pp.69-106.

[39] Yolcu, R. (2014): The effect of different irrigation levels and nitrogen fertilizer applied in different periods on yield and yield characteristics of silage corn irrigated with drip irrigation. - Cukurova Univ. Institute of Science, PhD Thesis, Adana, Turkey, 147p.

[40] Yurtsever, N. (1984): Experimental Statistics Methods. - Soil and Fertilizer Research Institute, General Publication No:121, Ankara, Turkey.

[41] Yururdurmaz, C. (2007): Determination of the effect of different fertilizer doses on different corn varieties in Kahramanmaras conditions and evaluation of the Ceres-Maize plant growth model. - Cukurova Univ. Institute of Science, PhD Thesis, Adana, Turkey, $242 \mathrm{p}$. 